\title{
Drought Tolerance of Navajo and Lovell Peach Trees: Precision Water Stress Using Automated Weighing Lysimeters
}

\author{
Will Wheeler, Reagan Wytsalucy, Brent Black, Grant Cardon, \\ and Bruce Bugbee ${ }^{1}$ \\ Department of Plants, Soils and Climate, Utah State University, 4820 Old \\ Main Hill, Logan, UT 84322
}

Additional index words. Prunus persica, rootstock, water stress, landrace cultivar

\begin{abstract}
Native American tribes have been cultivating peaches [Prunus persica (L.) Batsch] since their introduction to North America in the 1600s. In the American Southwest, peach orchards derived from centuries of seed selections have been maintained in relative isolation from commercial cultivars. These Native American peach selections may be better adapted to the arid climate of the Intermountain West. We compared physiological robustness during water stress of seedling peaches from a 60year-old orchard maintained by Navajo farmers in southwestern Utah to the commercial peach rootstock Lovell. Six replicate trees of each rootstock were subjected to eight cycles of controlled drought on an automated lysimeter system, which monitored transpiration rate continuously. Trees were selected for uniform size and transpiration rate at the start of the study. During the drought cycles, individual trees were watered when their transpiration rate decreased to less than $250 \mathrm{~g}$ of water per day, $\approx 20 \%$ of their wellwatered daily transpiration rate. After the first cycle of drought, the transpiration rate of the Navajo trees was greater than the Lovell trees, so they depleted their root-zone water more rapidly and experienced greater water stress. Despite greater stress, the Navajo selection had greater leaf area and dry weight at harvest. Because the root system was confined, these results indicate that the Navajo selection may have greater resilience when experiencing drought, independent of the depth and distribution of the root system. However, this study was not able to determine whether physiological resilience during drought was a result of canopy or root characteristics. Field studies are needed to determine whether root distribution or depth also contribute to drought tolerance in the Navajo selection.
\end{abstract}

Irrigated agricultural crops account for $70 \%$ of water consumption in the United States, and can be as high as $90 \%$ in some western states (Schaible and Aillery, 2017). Agricultural water scarcity is expected to increase as a result of increased population growth and climate change (Strzepek and Boehlert, 2010). Tree fruits such as peaches, apples, cherries, and apricots are high-value crops with some of the greatest

Received for publication 7 Dec. 2018. Accepted for publication 8 Mar. 2019.

Funding for this project was made possible by a U.S. Department of Agriculture-National Institute of Food and Agriculture Specialty Crop Block Grant administered by the Utah Department of Agriculture, the Utah Water Initiative grant program, and by the Utah Agriculture Experiment Station, Utah State University, journal paper no. 9148.

We thank the Tsinajinnie family for their donation of seed and continued support. We also thank the following people for their extensive technical support and intellectual contributions: Alec Hay, James Frisby, Lance Stott, Teryl Roper, and Dan Drost.

${ }^{1}$ Corresponding author. E-mail: bruce.bugbee@, usu.edu. water requirements (Fereres and Evans, 2006). In commercial orchard production, a fruiting scion is nearly always grafted onto a rootstock cultivar. Breeding and selection of rootstock cultivars frequently targets tree size and precocity, pest and disease resistance, and adaptability to different soils. Less effort has been devoted to the selection of rootstocks that might confer tolerance to drought (Ernst et al., 2012). Selection of rootstocks adapted to drought would benefit arid fruit-growing regions.

Native American populations in southwestern North America, including the Navajo, Hopi, and Zuni tribes, have been cultivating peaches for more than 400 years (Benavides, 1996). Native American cultivation practices differ dramatically from European production. Rather than relying on grafting to combine desirable stock and scions, seeds of desirable trees are collected and planted directly to form new orchards (Jett, 1977). Orchards receive no formal irrigation after initial establishment and often receive as little as $280 \mathrm{~mm}$ of annual precipitation (Singletary et al., 2014). Orchards were commonly planted below canyon rims, which historically receive precipitation runoff from mesa cliffs, as demonstrated by Navajo, Hopi, and Zuni historic orchard sites (Ferguson, 1996; Jett, 1979; Singletary et al., 2014). The seed selection of peaches from orchards in these remote locations over hundreds of years resulted in landrace-type populations that may have greater drought tolerance than commercial rootstock cultivars. Using these as rootstocks could improve the drought tolerance of modern orchards, requiring less irrigation.

Weighing lysimeters provide a reliable method of applying drought stress because the transpiration rate of an entire tree can be determined over short intervals, summed over a day and integrated over the study (Ben-Gal et al., 2010). Studies with lysimeters require that the plants be grown in a limited root zone, which eliminates the variable of root distribution and facilitates studies of physiological adaptation to stress. Several studies have compared rootstocks in containers in a greenhouse environment. A study of drought effects on apple rootstocks in a greenhouse withheld water and used single-leaf measurements of water potential and stomatal conductance to assess the magnitude of water stress (Tworkoski et al., 2016). This was a valuable study, but there are significant challenges in extrapolating from short-term measurements on single leaves to whole plants (Jones, 2004).
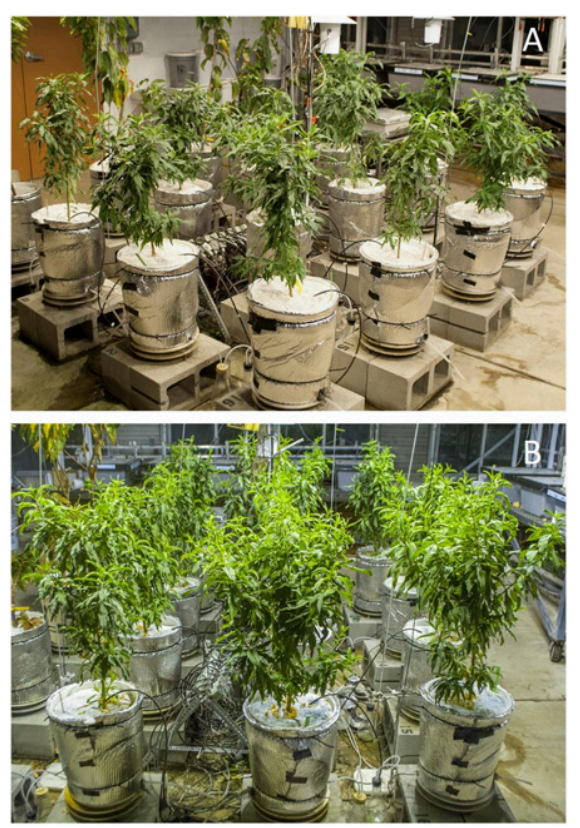

Fig. 1. Navajo and Lovell peach seedlings on the lysimeter system at the start of trial 1 (A) and trial 2 (B). The two lysimeter plates, enclosing the load cell, are visible at the bottom of the container. Containers were covered with a layer of perlite to minimize evaporation from the soil surface, and were wrapped with insulation to reduce daily temperature fluctuation of the root zone. The solenoids and drip lines are shown. Four drought cycles were imposed in the two trials, with a 2 -week recovery period between trials. 
A common technique in drought-stress container studies is to maintain a constant frequency of watering but reduce the volume of water applied. This leads to less negative water potential at the top of the container than the bottom because the hydraulic conductivity of soil declines exponentially with decreasing water content. This problem is even more significant in coarse-texture media (Hillel, 1998). Atkinson et al. (1999) studied drought in apple rootstocks in 14-L containers with a compost media; Chahal et al. (2018) imposed water stress for Amaranthus in 9-L containers with a silt loam soil. Both studies reduced the volume of water applied without changing the frequency of watering. Chahal et al. (2018) measured water potential or volumetric content carefully, but only in the top $30 \%$ of the container. Differences in root-zone water potential between the top and bottom of the container make it difficult to know the magnitude of water stress of the plant. Changing the frequency of watering, rather than the volume of water, provides a better method of regulating water stress because it allows uniform wetting of the root zone.

Both Tworkoski et al. (2016) and Atkinson et al. (1999) used potting soil as a medium, which is well aerated but is a poor substrate for drought studies because it has a rapid decrease in water potential over a narrow range of volumetric water content (Bunt, 1988; Handrek and Black, 2005). Weighing lysimeters facilitate the use of soil because overwatering and waterlogging can be avoided. The use of soil allows for a gradual decrease in water potential that better approximates field conditions. Lysimeters not only indicate volumetric water content of the entire container, they provide a realtime measurement of water stress via the hourly transpiration rate.
Our objective was to use weighing lysimeters for precision water stress to compare resilience during drought of a Navajo peach selection to the commercial seed-propagated rootstock cultivar Lovell.

\section{Materials and Methods}

Seeds from a Navajo peach landrace population were collected from an orchard near Navajo Mountain, UT, that has been maintained by native Navajo residents for at least 60 years. Peaches from the Navajo population are predominately white freestone, but can have yellow flesh. Irrigation is occasional, and thinning is not practiced, potentially contributing to a reduced fruit size vs. that of commercial varieties. The trees are shrublike as a result of no pruning practices. The seed selection was a subsample of all peach trees within the orchard. Efforts for further characterization of these

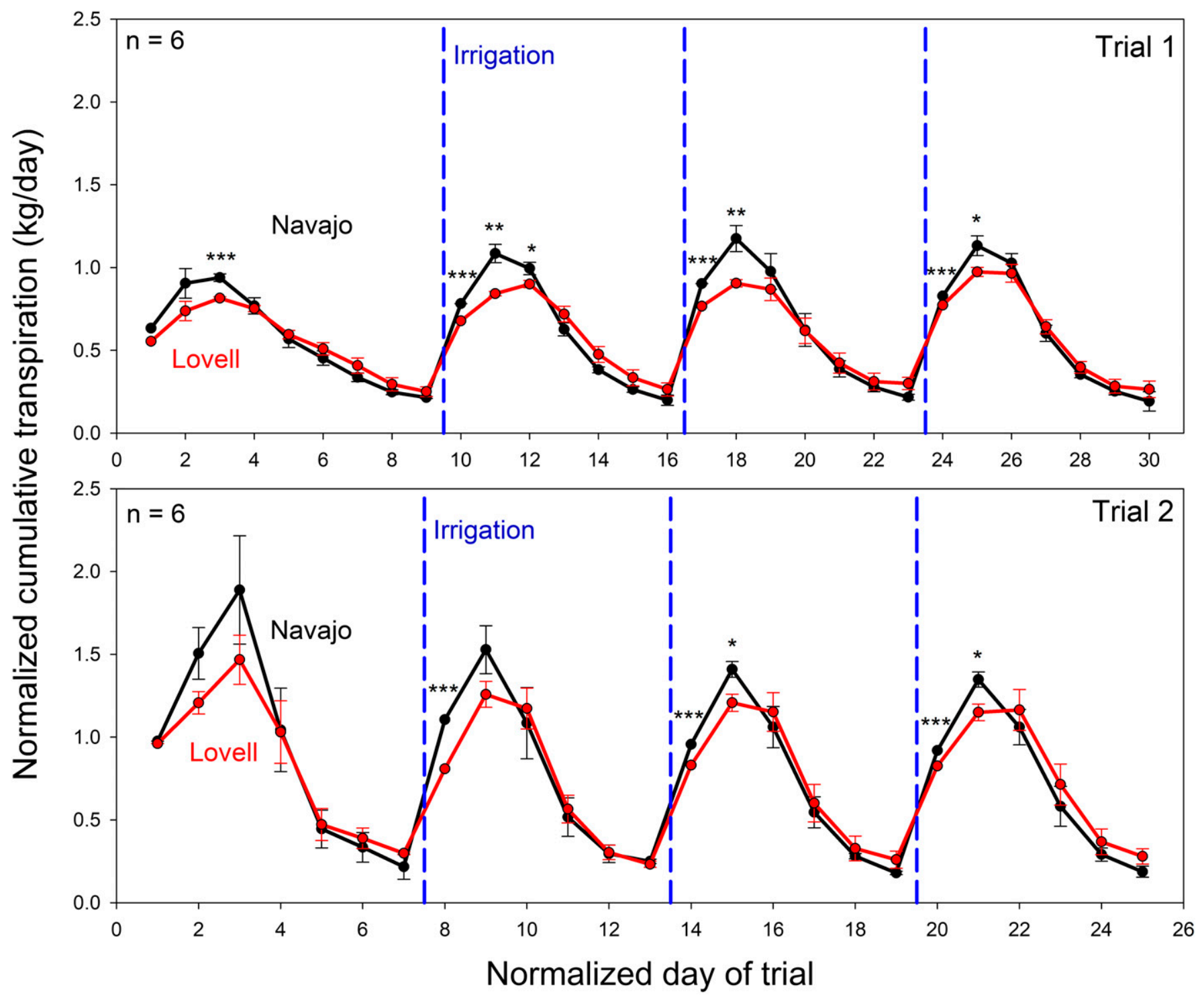

Fig. 2. Cumulative transpiration for Navajo (black line) and Lovell (red line; color in online version only) peach selections. Data were normalized to the first day of the trial. Cumulative transpiration rates were used to trigger irrigation and provide an indication of the size of the trees. When the cumulative transpiration of an individual tree fell to less than $250 \mathrm{~g}$ per day, irrigation was triggered, returning the soil to field capacity. Error bars indicate SE. ${ }^{*} P<0.05, * * P<0.01$, and $* * * P<0.001$. 
populations are ongoing. The peach cultivar Lovell was used as a control standard because it is a widely used seed-propagated rootstock. Lovell rootstock seeds were provided by a commercial source (Sierra Gold Nurseries, Yuba City, CA). Both selections were planted in 4-L containers filled with an $80 \%$ peat $/ 20 \%$ perlite media and were grown for 2 months with supplemental lighting in the Utah State University Research greenhouses. Plants were watered with a complete nutrient solution at 100 ppm N fertigation (Peters Excel 21N2.2P-16.6K; Everris, Dublin, $\mathrm{OH}$ ). When the root system reached the bottom of the containers, six trees from each seed source were selected for uniformity and were transplanted into $22-\mathrm{L}$ containers with a $90 \%$ silty clay loam $/ 10 \%$ peat mixture. Soil was a Battle Creek silty clay loam series obtained from an agricultural field located in Cove, UT (lat. $41^{\circ} 57^{\prime} 48^{\prime \prime} \mathrm{N}$, long. $\left.111^{\circ} 48^{\prime} 26^{\prime \prime} \mathrm{W}\right)$. Silty clay loam was used to achieve a longer, more gradual release of water in the container. Because of the addition of peat and careful soil placement in the container, the bulk density in the containers was $\approx 1.2 \mathrm{~kg} \cdot \mathrm{m}^{-3}$. The soil mixture had an initial electrical conductivity (EC) of $1.97 \mathrm{mS} \cdot \mathrm{cm}^{-1}$ and was irrigated with water that had an $\mathrm{EC}$ of $\approx 0.35 \mathrm{mS} \cdot \mathrm{cm}^{-1}$, so salt stress was judged to be minimal. To ensure ample nutrients, the soil was amended with $8 \mathrm{~g} \cdot \mathrm{L}^{-1}$ controlled-release fertilizer (Polyon 16N-2.6P-9.1K, 5- to 6month release; Pursell Industries, Sylacauga, AL). After $30 \mathrm{~d}$ of growth the trees were established in the larger containers. Each tree was visually equal in size at the start of the trial. Before the start of the first trial, Navajo trees had an average transpiration rate that was $4.3 \%$ greater than Lovell (593 vs. $\left.565 \mathrm{~g} \cdot \mathrm{d}^{-1}\right)$. During this pretrial period, differences were not statistically significant and the uniform transpiration rate indicated the relative uniformity of the trees. Peak transpiration rates, generally observed 2 to $3 \mathrm{~d}$ after the last irrigation event, increased to $\approx 1000 \mathrm{~g} \cdot \mathrm{d}^{-1}$ at the start of the trial.

Each container and its tree was then placed on a load cell platform in a 12-container weighing lysimeter system (Fig. 1). This greenhouse lysimeter system has been described in detail by Chard et al. (2016). Each container had two $2-\mathrm{L} \cdot \mathrm{h}^{-1}$ drip emitters at the surface, which were used to add water slowly until leaching was observed from drain tubes at the bottom. Before filling, porous ceramic cylinders $(1.5-\mathrm{cm}$ diameter $\times$ 6.5 -cm length; effective pore size, $\approx 1.7 \mu \mathrm{m}$ ) were installed at the bottom of each container by drilling a hole through the side wall and fixing the cups in place. After irrigation, when leaching was observed to stop, a vacuum $(-0.05 \mathrm{MPa})$ was connected to the porous ceramic cylinders and run overnight. This removed $\approx 250 \mathrm{~mL}$ additional water from each container. The container surface was then covered with $5 \mathrm{~cm}$ perlite to minimize surface evaporation. The combined weight of each tree and container was then determined $(\approx 22-27$ $\mathrm{kg} /$ tree) and programmed into the measurement and control software as the near-fieldcapacity baseline weight.

Transpiration rates were determined every $30 \mathrm{~min}$ from the change in container weight, summed daily, and a cumulative transpiration total was calculated at midnight. Trees were irrigated when the daily cumulative transpiration decreased to less than a programmed threshold of $250 \mathrm{~g} /$ tree/d. This change represented an approximate $80 \%$ decline in daily transpiration from maximum, or peak, daily transpiration totals after irrigation. This threshold was selected because it was associated with visual wilting of the leaves. The transpiration rate of each tree was measured independently and irrigated automatically using a data loggerbased controller. After each drought cycle, containers were drip-irrigated back up to the near-field-capacity baseline weight. To allow daily measurements of transpiration, plants were irrigated only at night. Irrigation cycled on for $15 \mathrm{~s}$ each minute to minimize ponding and allow for slow percolation of water into the soil. This slow irrigation (up to $6 \mathrm{~h}$ ) preserved the soil structure and airfilled porosity during the trial. Each tree was subjected to four dry-down and irrigation cycles, followed by a 2 -week well-watered recovery period, and then four additional dry-down and irrigation cycles, for a total of eight drought and six recovery events.

Internal circulation fans in the greenhouse minimized variation in temperature and humidity. During the first trial, the average day/night temperature was 28.9/ $20.3^{\circ} \mathrm{C}$ and was $27.8 / 18.2{ }^{\circ} \mathrm{C}$ in the second trial. The vapor pressure deficit averaged 3.2 $\mathrm{kPa}$ for the first trial and $2.5 \mathrm{kPa}$ for the second trial. The $\mathrm{CO}_{2}$ concentration was ambient $(\approx 400 \mathrm{ppm})$ for both trials. Supplemental lighting was provided by four, 1000 W high-pressure sodium fixtures arranged to provide a uniform photosynthetic photon flux density at the canopy surface. Trees were arranged in a complete randomized design to minimize any potential differences in lighting intensity. The integrated daily photon flux density (measured with multiple replicate full-spectrum quantum sensors, model SQ-500; Apogee Instruments, Logan, UT) averaged $45.5 \mathrm{~mol} \cdot \mathrm{m}^{-2} \cdot \mathrm{d}^{-1}$ for the first trial and $41.6 \mathrm{~mol} \cdot \mathrm{m}^{-2} \cdot \mathrm{d}^{-1}$ for the $\mathrm{sec}-$ ond trial. These values are about $85 \%$ of full summer sunlight under regional field conditions.

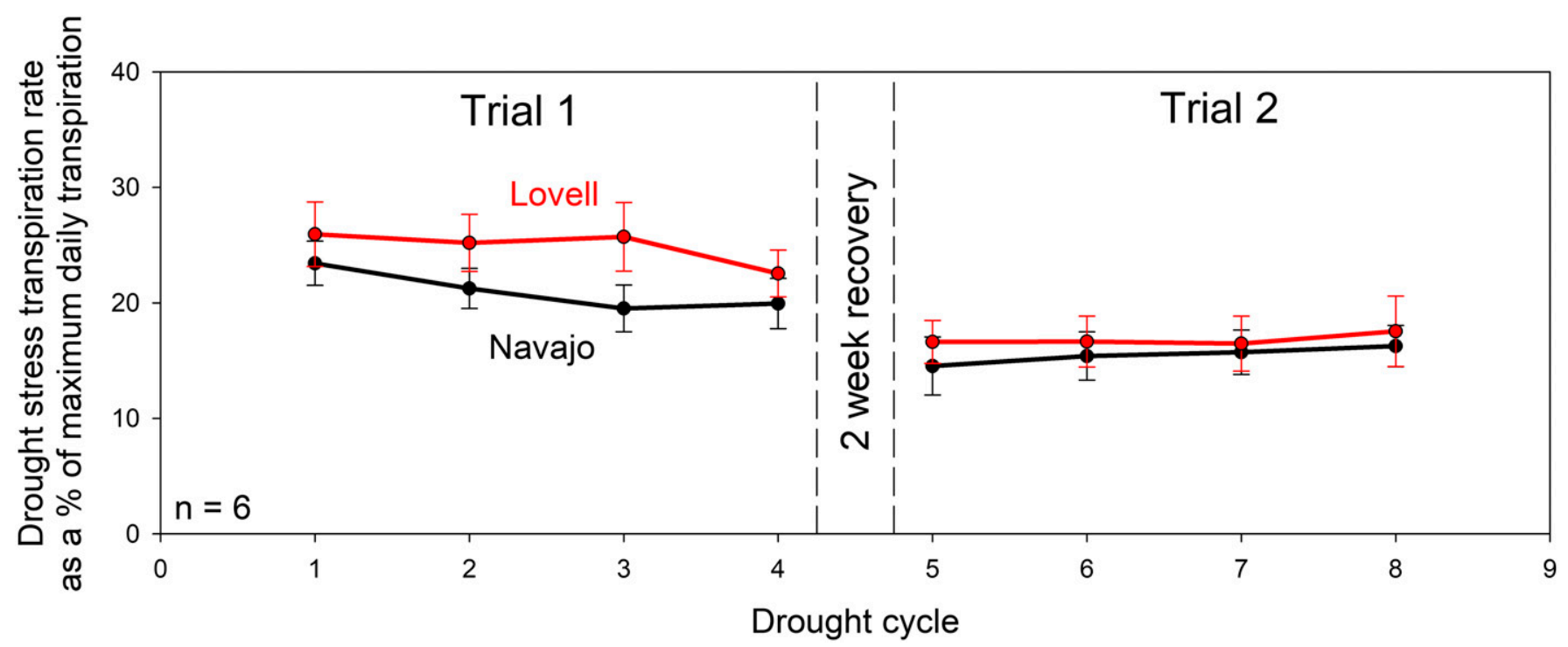

Fig. 3. Daily transpiration rate during maximum drought stress as a percentage of the maximum daily well-watered transpiration rate. There were four drought cycles in each trial. Each load cell was controlled independently. When cumulative transpiration fell to less than $250 \mathrm{~g}$ per day, irrigation was triggered. Because the Navajo trees grew more rapidly during the trial, they had a greater transpiration rate and thus were subject to greater stress, as indicated by the lower percentage of the maximum daily transpiration rate at the time of irrigation. Error bars indicate SE. The differences in drought stress between selections was statistically significant in trial $1(P=0.02)$ but not in trial 2 . 
Trees were harvested destructively at the end of the second trial. Trunk diameter at $3 \mathrm{~cm}$ above the soil surface was measured and the cross-sectional area was calculated. Chlorophyll was measured on 10 recently developed, fully expanded leaves per tree using a handheld chlorophyll meter (model MC-100; Apogee Instruments). Leaves were removed and counted, and the area was measured (model LI-3100C area meter; LI-COR, Lincoln, NE). Leaf and wood tissue dry weight were measured after drying for $3 \mathrm{~d}$ at $80^{\circ} \mathrm{C}$. Root balls were removed from their containers and shaken to remove bulk soil, weighed, evaluated visually, and photographed.

The six replicate trees were arranged in a completely randomized design, with seed sources treated as fixed effects. Cumulative transpiration and number of dry-down days were analyzed using two-way repeated measures multivariate analysis of variance (ANOVA). All other variables were analyzed using two-way ANOVA. Trees dried down to threshold transpiration rates over a variable number of days, which resulted in irrigation frequency differing for each tree. Cumulative transpiration was normalized in the graphs so that the start of each drought cycle began with the first day after an irrigation event for all trees. The total number of dry-down days was averaged and the graph was normalized to reflect that average. All data were analyzed using R statistical software (R Foundation for Statistical Computing, Vienna, Austria).

\section{Results and Discussion}

The time between irrigation intervals was shorter for the larger trees, but individual trees were watered when transpiration decreased to less than $250 \mathrm{~g} /$ tree $/ \mathrm{d}$. In practice, transpiration rates always declined below this threshold, with minimum daily transpiration rates averaging $220 \mathrm{~g} /$ tree/day for the first trial and $205 \mathrm{~g} /$ tree/d for the second trial. Comparing these minimum values to peak daily transpiration rates observed after the last irrigation event (initially around $1000 \mathrm{~g} /$ tree $/ \mathrm{d}$ ), the minimum transpiration rates represent $22.5 \%$ of peak daily transpiration for the first trial and $16 \%$ for the second trial. As trees approached lower threshold transpiration rates, there was visible wilting of the leaves throughout the canopy; during the subsequent recovery periods, leaf necrosis and abscission were observed in all trees. Girona et al. (2002) used a similar reduction to $20 \%$ of maximum tree evapotranspiration and reported $\approx 80 \%$ reduction in stem water potential by the end of the dry-down period.

Osmotic adjustment of Prunus species has been reported to occur after prolonged, gradual dry-downs, most commonly observed under field conditions or carefully controlled greenhouse studies (Arndt et al., 2000; Jiménez et al., 2013). Through this mechanism, leaf turgor can be maintained under stress, although species vary greatly in their capacity for osmotic adjustment (Abrams, 1994). Mellisho et al. (2011) reported that Prunus persica (L.) Batsch cv. Flordastar grafted to the $P$. persica $\times$ Prunus amygdalus GF-677 rootstock did not have sufficient osmotic adjustment to overcome the turgor loss point in leaves. Their study used eight cyclic periods of 7 to $9 \mathrm{~d}$ of withholding irrigation and it is uncertain whether osmotic adjustment occurred in either rootstock or to

Table 1. Destructive harvest parameters for the two peach selections. The Navajo selection had greater leaf area $(P=0.05)$, leaf dry weight $(P=0.05)$, and number of leaves $(P=0.01)$ than the commercially available rootstock Lovell. Both selections were drought stressed eight times to approximately $20 \%$ of their peak transpiration rates. The Navajo selection had greater average peak transpiration and more leaf area and mass than Lovell, suggesting it has greater physiological resilience during water stress.

\begin{tabular}{|c|c|c|c|c|c|c|}
\hline Cultivar & Trunk and stem dry wt $(\mathrm{g})$ & Trunk diam $(\mathrm{cm})$ & Total leaf area $\left(\mathrm{m}^{2}\right)$ & Leaf dry wt (g) & No. of leaves/tree & Root ball wt (g \\
\hline Navajo & 106 & 1.57 & 1.27 & 95.8 & 847 & 1,625 \\
\hline Lovell & 97 & 1.55 & 0.98 & 79.1 & 568 & 1,197 \\
\hline Ratio & 1.10 & 1.01 & 1.29 & 1.21 & 1.49 & 1.36 \\
\hline Significance & NS & NS & 0.05 & 0.05 & 0.01 & NS \\
\hline
\end{tabular}

NS $=$ not significant.

\section{Navajo}
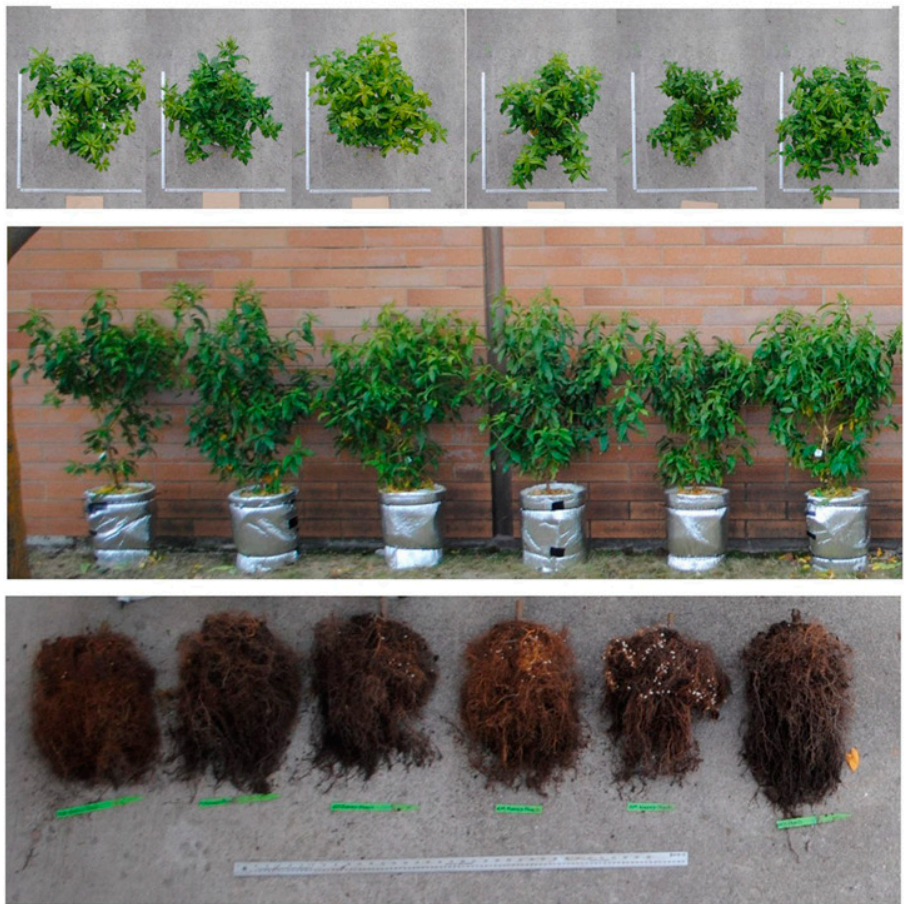

\section{Lovell}
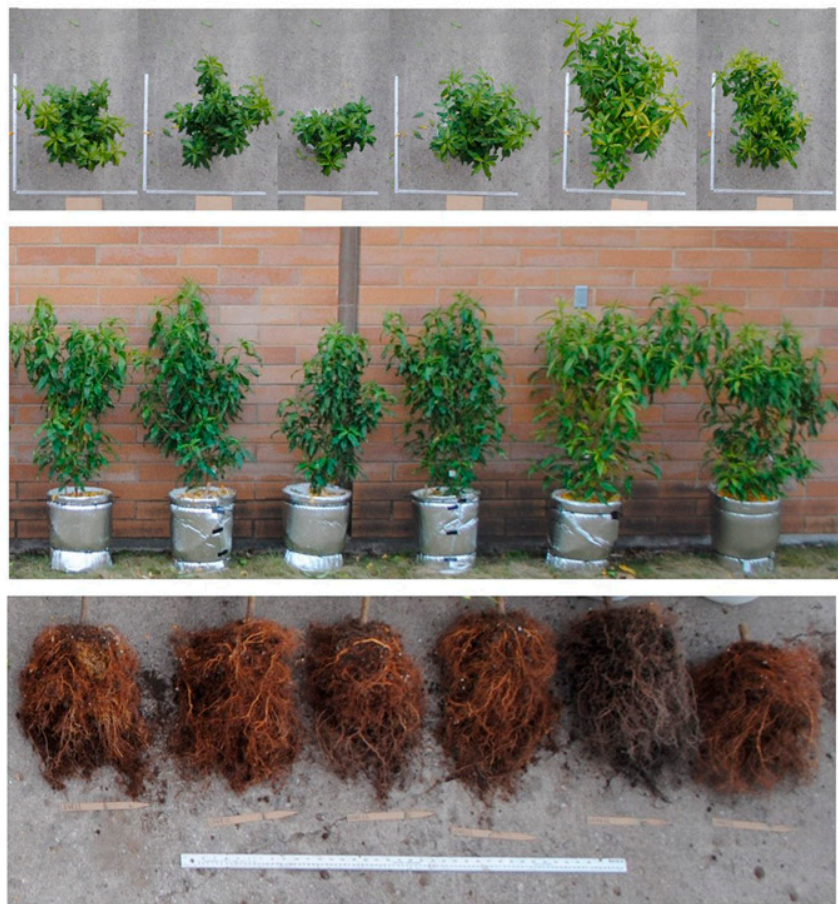

Fig. 4. Navajo and Lovell peach trees at harvest. The increased leaf area and leaf number are visually apparent in the photo. Navajo trees tended to have more horizontal branching than Lovell. Although the Navajo root ball weight was $36 \%$ greater than the Lovell, the difference was not statistically significant. 
what extent it may have contributed to resilience.

Despite drought stress, in our study both genotypes recovered to their predrought peak transpiration rates within $3 \mathrm{~d}$ of rewatering (Fig. 2). For the entire first trial and the last two drought events of the second trial, Navajo had greater peak transpiration rates. As a result, the Navajo selection experienced greater drought stress as a percentage of peak daily transpiration in the first trial $(P=0.02)$. The Navajo selection also tended to have greater drought stress in the second trail, but the difference was not statistically significant (Fig. 3).

At harvest, the Navajo selection had a $16 \%$ greater leaf dry weight per tree $(P=$ $0.05)$, a $32 \%$ greater number of leaves $(P=$ $0.01)$, and a $30 \%$ greater leaf area $(P=0.05)$ (Table 1). Because the trees were of equal size at the start of the trials, these differences reflect increased growth of the Navajo selection during the trial, despite slightly greater drought stress. Transpiration rate is highly correlated with $\mathrm{CO}_{2}$ uptake, photosynthesis, and growth of trees (Adams et al., 2018; Bréda and Granier, 1996; Obojes et al., 2018; Welander and Ottosson, 2000), so reduced transpiration rates are a good indicator of reduced whole-tree photosynthesis and dry weight gain. Higher measurements of leaf biomass at harvest confirm that the differences in transpiration rate during the trial were associated with growth differences. Rieger and Duemmel (1992) reported that shoot characteristics in six cultivated peach species correlated more with drought adaption than root characteristics. In our study, there was no significant difference between specific leaf area of the Navajo and Lovell rootstocks (13.3 and $12.4 \mathrm{~m}^{2} \cdot \mathrm{kg}^{-1}$, respectively), which suggests that leaf contribution to resilience during water stress may be minimal. However, because these were ungrafted rootstocks, adaption of the shoot may have contributed to the resilience of the tree to water stress. Further studies with each rootstock grafted to a common scion could help differentiate rootstock from scion effects.

There were no statistically significant differences in trunk cross-sectional area or trunk dry weight at harvest (Table 1). The root systems of both genotypes were vigorous and healthy (Fig. 4). Although the Navajo selection tended to have a greater root-ball fresh weight at harvest, the difference was not statistically significant (Table 1). Leaf chlorophyll concentration was slightly greater in Lovell (data not shown), but the difference was not visually apparent and the high chlorophyll concentration in both cultivars indicated ample nutrition. Visually, the Navajo selection had a slightly more horizontal branch orientation (Fig. 4).

\section{Conclusions}

This study indicates that the Navajo selection is physiologically more robust under drought conditions than Lovell rootstock when root volume is held constant. Commercial peach rootstocks in the field can differ in root distribution (Black et al., 2010). Additional work is needed to determine how root distribution compares between the Navajo selection and commercial rootstocks, as well as how the differences observed here translate into differences in field-based drought response. The historic peach landraces developed by traditional Native American farmers in the American desert Southwest may provide useful traits to commercial breeders in the development of rootstocks and scion cultivars adapted to arid environments.

\section{Literature Cited}

Abrams, M.D. 1994. Genotypic and phenotypic variation as stress adaptations in temperate tree species: A review of several case studies. Tree Physiol. 14:833-842.

Adams, S., J. Lordan, G. Fazio, B. Bugbee, P. Francescatto, T.L. Robinson, and B. Black. 2018. Effect of scion and graft type on transpiration, hydraulic resistance and xylem hormone profile of apples grafted on Geneva ${ }^{\circledR} 41$ and M.9-NIC ${ }^{\text {TM}} 29$ rootstocks. Scientia Hort. 227:213-222.

Arndt, S.K., W. Wanek, S.C. Clifford, and M. Popp. 2000. Contrasting adaptations to drought stress in field-grown Ziziphus mauritiana and Prunus persica trees: Water relations, osmotic adjustment and carbon isotope composition. Funct. Plant Biol. 27:985-996.

Atkinson, C.J., M. Policarpo, A.D. Webster, and A.M. Kuden. 1999. Drought tolerance of apple rootstocks: Production and partitioning of dry matter. Plant Soil 206:223-235.

Benavides, F.A. 1996. A harvest of reluctant souls: The memorial of Fray Alonzo de Benavides, 1630. Trans. B.H. Morrow. University Press of Colorado, Boulder, CO.

Ben-Gal, A., D. Kool, N. Agam, G.E. van Halsema, U. Yermiyahu, A. Yafe, E. Presnov, R. Erel, A. Majdop, I. Zipori, E. Segal, S. Ruger, U. Zimmermann, Y. Cohen, V. Alchanatis, and A. Dag. 2010. Whole-tree water balance and indicators for short-term drought stress in nonbearing 'Barnea' olives. Agr. Water Mgt. 98:124-133.

Black, B.L., D. Drost, T. Lindstrom, J. Reeve, J. Gunnell, and G.L. Reighard. 2010. A comparison of root distribution patterns among Prunus rootstocks. J. Amer. Pomol. Soc. 64:52-62.

Bréda, N. and A. Granier. 1996. Intra- and interannual variations of transpiration, leaf area index and radial growth of a sessile oak stand (Quercus petraea). Ann. Sci. For. 53:521-536.

Bunt, A.C. 1988. Media and mixes for containergrown plants. 2nd ed. Unwin Hyman, London, UK.

Chahal, P.S., S. Irmak, M. Jugulam, and A.J. Jhala. 2018. Evaluating effect of degree of water stress on growth and fecundity of Palmer amaranth (Amaranthus palmeri) using soil moisture sensors. Weed Sci. 66:738-745.
Chard, J., M. van Iersel, and B. Bugbee. 2016. Mini-lysimeters to monitor transpiration and control drought stress: System design and unique applications. 12 Sept. 2018. <https:// www.semanticscholar.org $>$.

Ernst, T., S.D. Rowley, B.L. Black, and T.R. Roper. 2012. Reviewing potential local fruit markets: A Utah case study. J. Amer. Pomol. Soc. 66:16-22.

Fereres, E. and R. Evans. 2006. Irrigation of fruit trees and vines: An introduction. Irrig. Sci. 24:55-57.

Ferguson, T.J. 1996. Historic architecture \& society. University of Arizona Press, Tucson, AZ.

Girona, J., M. Mata, E. Fereres, D.A. Goldhamer, and M. Cohen. 2002. Evapotranspiration and soil water dynamics of peach trees under water deficits. Agr. Water Mgt. 54:107-122.

Handrek, K.A. and N.D. Black. 2005. Growing media for ornamental plants and turf. University of New South Wales Press Ltd., Sydney NSW, Australia.

Hillel, D. 1998. Environmental soil physics. Academic Press, San Diego, CA.

Jett, S.C. 1977. History of fruit tree raising among the Navajo. Agr. Hist. 51:681-701.

Jett, S.C. 1979. Peach cultivation and use among the Canyon de Chelly Navajo. Econ. Bot. 33:298-310.

Jiménez, S., J. Dridi, D. Gutiérrez, D. Moret, J. J. Irigoyen, M. A. Moreno, and Y. Gogorcena. 2013. Physiological, biochemical and molecular responses in four Prunus rootstocks submitted to drought stress. Tree Physiol. 33:1061-1075.

Jones, H.G. 2004. Irrigation scheduling: Advantages and pitfalls of plant-based methods. J. Expt. Bot. 55:2427-2436.

Mellisho, C.D., Z.N. Cruz, W. Conejero, M.F. Ortuño, and P. Rodríguez. 2011. Mechanisms for drought resistance in early maturing cvar Flordastar peach trees. J. Agr. Sci. 149:609616.

Obojes, N., A. Meurer, C. Newesely, E. Tasser, W. Oberhuber, S. Mayr, and U. Tappeiner. 2018. Water stress limits transpiration and growth of European larch up to the lower subalpine belt in an inner-alpine dry valley. New Phytol. 220:460-475.

Rieger, M. and M.J. Duemmel. 1992. Comparison of drought resistance among Prunus species from divergent habitats. Tree Physiol. 11:369380 .

Schaible, G.D. and M.P. Aillery. 2017. Challenges for US irrigated agriculture in the face of emerging demands and climate change, p. 4479. In: J. Ziolkowska and J.M. Peterson (eds.). Competition for water resources. Elsevier, Cambridge, MA.

Singletary, L., S. Emm, M. Loma'omvaya, J. Clark, M. Livingston, M.K. Johnson, and R. Oden. 2014. People of the land: Sustaining agriculture on the Hopi reservation. Univ. of NV. Coop. Ext. Reno, NV.

Strzepek, K. and B. Boehlert. 2010. Competition for water for the food system. Phil. Trans. R. Soc. B 365:2927-2940.

Tworkoski, T., G. Fazio, and D.M. Glenn. 2016. Apple rootstock resistance to drought. Scientia Hort. 204:70-78.

Welander, N.T. and B. Ottosson. 2000. The influence of low light, drought and fertilization on transpiration and growth in young seedlings of Quercus robur L. For. Ecol. Mgt. 127:139-151. 